\title{
The Effect of Shyness on Iranian EFL Learners' Language Learning Motivation and Willingness to Communicate
}

\author{
Tannaz Mohammadian \\ Department of English Language, Azad University, Shiraz, Iran
}

\begin{abstract}
The present study intends to investigate the effect of shyness on Iranian EFL learners' language learning motivation and willingness to communicate. In western countries shyness has been considered as an undesirable personality trait that may interfere with one's interpersonal interactions and affect life satisfaction. However, shyness is viewed differently in Iranian cultures. In Iranian society, people are encouraged to control their personal desires. Among the variables that influence L2 learning, shyness and language learning motivation are two critical predictors, whereas willingness to communicate also often influences learners' performance in L2 communication. This study was conducted with 60 EFL learners who were taking English courses at a private English institute in Shiraz. They were asked to fill out self-report questionnaires about their shyness, motivations in their English studies, and their willingness to communicate. Results indicated that intrinsic motivation to accomplish appears to be the most important predictor among all motivation regulations for all students. Results also indicated that shyness and language learning motivations were positively correlated.
\end{abstract}

Index Terms - shyness, motivation, willingness to communicate

\section{INTRODUCTION}

The experience of learning a foreign language is both mentally and emotionally demanding for most learners. Most second or foreign languages are learned in classrooms, where there is constant performance evaluation by the teachers and peers. This situation can be frightening for most learners, especially those who are shy, due to their desire for approval from others and fear of negative evaluation.

In an English-as-a-foreign-language (EFL) class, especially a class that emphasizes speaking and listening, shy students seem to be at a great disadvantage since they do not draw attention to themselves, either by not volunteering to answer questions in class, or by avoiding opportunities for oral communication. In fact, some research has revealed that extroverts are a lot better in formal situations or interpersonal encounters when compared to their introverted counterparts (Dewaele \& Furnham, 2000). However, there are examples of shy EFL learners becoming proficient regardless of their timidity in language classes (Anthony, 1963; Entwistle, 1972; Morris, 1979).

The nature of shyness has been already researched in the literature (e.g., Buss, 1980; Cheek \& Buss, 1981; Jones \& Russell, 1982; Leary \& Schlenker, 1981; Chuh, 2008). Experience of feeling shy is a common experience that most of us have experienced; however, the frequency and the magnitude of feelings of shyness vary from person to person. Individuals who are terribly shy may pass up opportunities to form intimate relationships with peers and the opposite sex or meet other like-minded people. (Caspi, Elder, \& Bem, 1988). They may lose the opportunity to be heard by their teachers or professors at school (Friedman, 1980), or even to show their employers their usefulness at work.

Researches on second language acquisition show that affective factors like motivation and willingness to communicate play an important role in language achievement (Yashima, 2002). Gardner and Lambert (1959) identify two categories of motivation: first, integrative motivation which is a positive tendency towards the second language group and desire to interact with and become a member of that group, and second, instrumental motivation which is related to pragmatic goals of learning a second language. The importance of motivation in language learning is intertwined with the importance and role of motivation in learning a second language. Gardner and Lambert (1959, 1972) suggested that a person's motivation for learning a second language is affected by motivation for acquisition of the second language and the attitude towards second language group.(Zarinabadi, 2011)

In recent years, researchers in both fields of psychology and second language learning have used motivation theories such as Self-Determination Theory (Deci \& Ryan, 2002) to explain the motivation of L2 learners. The process of learning a new language is often lengthy and complicated, so it is not difficult to imagine that learners need to maintain motivation in order to learn the language. Lack of motivation can prevent a learner from obtaining the necessary information needed to perform a task. When this is paired up with extreme shyness, it can lead to failure in the L2 learning process.

Another affective factor is willingness to communicate (WTC), a variable which influences authentic communication in L2 and has been considered as an important predictor of frequency of communication.(Zarinabadi, 2011). Dörnyei 
(2003) argues that many L2 learners stay away from second language communication. Kang (2005) states many L2 learners may not use the opportunities to learn language through authentic communication. MacIntyre et al. (1998) believe that producing WTC is an important component of modern language instruction. They argue that recent emphasis on communicative competence may produce students who are capable of communication inside the classroom, but "may not be amenable to do so outside the classroom."(p. 549) Kang (2005) reports teachers can have more active learners by making them more willing to communicate. Kang states that students with high WTC are more likely to use L2 in authentic communication. He also believes that students with high WTC will become involved in learning activities both inside and especially outside the classrooms. Scholars like Dörnyei (2005) consider WTC as the ultimate goal of instruction. (Zarinabadi, 2011) Researchers have conducted studies on the influence of an individual's variables on WTC. Shyness was found to be as one of the important factors.

Now we know that shy students can be at a serious disadvantage in class in comparison with more extrovert students. As a result, they might get less attention from the instructors and their abilities might be underestimated. So if shy students, their motivation, and their level of willingness to communicate are identified, instructors can use special techniques and strategies to modify their instructions in handling these types of students.

This study investigates how shy learners, who are likely low in extroversion, manage their language learning tasks, drawing on the literature of language learning motivation, and willingness to communicate.

In the present study, an attempt is made to examine the effects of shyness on language learning orientation and willingness to communicate among Iranian EFL learners. Most specifically, the study aims to know if there is any relationship between language learning orientation and willingness to communicate and whether they are affected by shyness. Thus, the following research questions are to be answered:

1. Do shy and non-shy students report having different types of motivation in EFL learning?

2. Do shy and non-shy learners show different levels of willingness to communicate?

3. Is there a relationship between Iranian EFL learners' language learning motivation and their willingness to communicate?

4. Is there a relationship among Iranian EFL learners shyness, their language learning motivation and their willingness to communicate?

\section{LITERATURE REVIEW}

\section{A. Nature of Shyness}

The nature of shyness has been widely researched in literature. There seems to be a discrepancy among the ideas of researchers: a group of scholars believe that it is a form of social anxiety (Buss, 1980), others believe it is a avoidant behavior (Phillips, 1980), still others view it as both, a manifestation of feelings of anxiety along with inhibited or avoidant behavior (Polman et al. 2004) Shyness has also been associated with other types of social anxiety, such as, stage fright, embarrassment, and shame.

\section{B. Second Language Learning Motivation Theories}

\section{The Canadian Socio-Psychological Camp}

The most important work conducted in the area of motivation in language study is a series of studies conducted by Robert Gardner and his colleagues (earlier with Wallace Lambert, and later with research associates at the University of Western Ontario). The original theory was derived from Mowrer's ideas (1950) on how identification with a valued person could influence one's development (cited in Skehan, 1989). Building on this idea, Gardner and Lambert (1959, 1972) considered the extent to which people regard and want to identify with not only particular individuals but also foreign people and culture, and proposed two types of motivation, integrative and instrumental, for learners who make attempts at learning a foreign language. Learners who have integrative orientation generally identify with the people in the target language group, have the curiosity to understand its culture, and may even want to be accepted as a member by the language community. On the other hand, learners with instrumental orientation are those who learn a foreign language with a utilitarian perspective, i.e., for their career advancement or survival in the society of the target language. Gardner and Lambert (1972) hypothesized that having an instrumental motive is less effective for a language learner because, unlike integrative motivation, it is not based on the personality of a learner and therefore, more contingent on fallible external pressures. Consequently, a learner with instrumental motivation may not expend as much effort to achieve cumulative progress over time.

Following a series of studies, Gardner and Smythe (1975) put forth a prototype of the Socio-Educational Model. In the model, they identified possible motivational characteristics in terms of four categories, Group Specific Attitudes, Course Related Characteristics, Motivational Indices, and Generalized Attitudes. Later, Gardner (1979) proposed a modification of this model in which he distinguished four components, the Social Milieu, Individual Differences, Second Language Acquisition Contexts, and Outcomes. In addition, he presented a schematic model in which attitudes were shown to affect motivation, which in turn influenced language achievement. In addition, Gardner asserted that achievement can be manifested in both linguistic and non-linguistic outcomes, which in turn had an impact on attitudes. Therefore, the model is seen as a positive feedback cycle in which attitudes and motivation influence language achievement, which in turn has an influence on subsequent attitudes and motivation. The model has undergone a 
number of revisions since its first publication (see Gardner, 1985; Gardner, 2001; Gardner \& MacIntyre, 1993). In the latest version, the category of External Influences replaces that of the Social Milieu of earlier versions. History (e.g., socio-cultural milieu in which the individual lives and personal background) and Motivators (e.g., the teacher's role in language learning) fall in this category. As for the other three categories, Individual Differences (e.g., integrativeness, attitude, aptitude, and motivation), Language Acquisition Contexts (i.e., formal vs. informal), and Outcomes (e.g., language proficiency or language anxiety) stay the same.

2. Self-Determination Theory

Self-determination theory was put forth by Deci and Ryan $(1985,2002)$ and is focused on various types of intrinsic and extrinsic motives and how those motives help people meet their needs for competence. Intrinsic motivation generally refers to the motivation to engage in an activity for its own sake because it is enjoyable. According to Deci and Ryan (1985), intrinsic motivation is based on one's need for competence and autonomy. They hypothesized that when people voluntarily choose to take part in an activity, they will look for possible interesting opportunities where they face the challenges that the activity brings forth. By trying to live up to the challenges, individuals develop a sense of competence in their ability. In recent years, (Vallerand et al., 1992, 1993) have presented a more fine-grained differentiation for the three subtypes of intrinsic motivation (IM). The first type is IM-Knowledge, the motivation to participate in an activity for the opportunities to acquire knowledge. The second type, IM-Accomplishment, refers to the feeling pertinent to mastering a task or achieving a goal. The third type, IM-Stimulation, concerns the sensations stimulated by performing a task, such as aesthetic appreciation or excitement.

The common ground for these three subtypes of intrinsic motivation is the satisfying sensations an individual experiences during the self-initiated challenging activity. By contrast, extrinsic motivation is a motive that prompts an individual to carry out a task simply to get a reward or to avoid punishment. This type of motivation does not necessarily imply the lack of self-determination in the behaviors performed. Instead, Deci and Ryan (1985) claimed that different types of extrinsic motivation (EM) can be categorized according to the extent to which they are internalized into the self-concept. According to Deci and Ryan, four levels of EM can be identified: external regulation, introjected regulation, identified regulation, and integrated regulation. External regulation is defined as activities that are determined by sources external to the person, such as perceivable benefits or costs, echoing the definition of Gardner's instrumental motivation. The second type of extrinsic motivation is introjected regulation, which is more internalized into the self-concept than external regulation. It occurs when individuals undertake an activity due to some kind of pressure or beliefs that they have assimilated into their self-concept, such that they make themselves perform the activity.

Although the source of the pressure comes from within, it is not self-determined because individuals are reacting to a demand rather than acting on the basis of free will. Identified regulation is considered to be more self-determined than introjected regulation. When people have this type of motivation, they choose to participate in an activity for personally relevant reasons that they value. The most autonomous form of extrinsic motivation is integrated regulation, occurring when identified regulations are fully incorporated into the self, which means they have been evaluated and come into line with other values a person has (Ryan \& Deci, 2000).

\section{Willingness to Communicate}

The importance of Willingness to Communicate (WTC) arises from the research of interaction-driven L2 development (Long, 1996; Mackey \& Gass, 2006; Swain, 2005). Researchers in this area have contended that language learning is facilitated through meaningful interactions. With an increasing emphasis on authentic communication in L2 learning and instruction, a willingness to communicate on the part of learners is deemed to have multiple advantages such as an increase of exposure and practice in authentic L2 communication and development of learner autonomy (MacIntyre et al., 2001; Kang, 2005). In this section, I will present several models that researchers have put forth in the WTC literature and discuss factors that affect an individual's WTC behavior.

1. McCroskey's Willingness-To-Communicate Model

Originating from the early work of Philips $(1965,1968)$ on reticence, of Burgoon (1976) on unwillingness to communicate, and of Mortesen, Arntson, and Lustig (1977) on predisposition toward verbal behavior, the idea of Willingness to Communicate (WTC) was first put forth by McCroskey and his associates (McCroskey \& Baer, 1985; McCroskey \& Richmond, 1987) with reference to L1 use and speaking as its focus. WTC was considered as "an individual's predisposition to initiate communication with others" (McCroskey, 1997, p.77), and posited to remain stable across situations. McCroskey and McCroskey (1986a) found that L1 WTC was negatively associated with communication apprehension, introversion, alienation, and anomie. On the other hand, they also found WTC to be positively associated with self-esteem and self-perceived communication competence (McCroskey \& McCroskey, 1986a, 1986b). In addition, Chan and McCroskey (1987) found that students who scored high on the WTC scale were more likely to participate verbally in class than those who scored low on WTC.

2. MacIntyre's and Clement's Willingness-To-Communicate Models

Despite what described above, some researchers believe that it is not a good idea to treat willingness to communicate (WTC) as a trait-like attribute, since WTC could be situation-specific and not transferable from L1 to L2. Clement and MacIntyre are two supporters of this view. In Clement's Social Context Model (Clement, 1980; Clement \& Kruidenier, 1985), he described the correlations among intergroup contact, L2 confidence, L2 competence, and L2 identity. The 
model suggested that the frequency and quality of contacts with the L2 community would eventually lead to variations in L2 confidence, which he saw as composed of perceived communicative competence and lower levels of L2 anxiety. In addition, L2 confidence was associated with an increase in communication competence in L2, identification with the L2 community, and assimilation motive. (Clement et al., 2003; Noels \& Clement, 1996; Noels, Pon, \& Clement, 1996). However, this model does not deal with L2 usage.

You may indicate that the previous literature described in the domain of shyness, motivation and willingness to communicate is inadequate and many new research questions can be raised in these fields. In general, there have been few studies investigating the relationship between shyness, motivation and willingness to communicate.

\section{MethodolOGY}

\section{A. Participants}

The participants recruited for this study were 60 students ( 30 males and 30 females) who were taking English as a foreign language courses at Management and Technology Institute in Shiraz. They were all native speakers of Persian, with an average age of 20.5 years. The youngest participant was 18 years of age, and the oldest was $44(\mathrm{SD}=2.12)$. They were chosen randomly, and since comprehension of the items in the questionnaire required a certain level of proficiency, advanced level students were chosen for the study.

\section{B. Instruments}

\section{The Revised Cheek and Buss Shyness Scale (RCBS)}

The shyness scale selected for this study was the 13-item Revised Cheek and Buss Shyness Scale (Cheek, 1983), first developed by Cheek and Buss in 1981 as a 9-item scale. The items are answered on a 5-point Likert scale, with 1 labeled as very uncharacteristic or untrue and 5 as extremely characteristic or true. The scale has been used frequently throughout the shyness literature for its sound psychometric properties (Bradshaw, 1998; Heiser et al., 2003; Paulhus \& Trapnell, 1998; Schmidt \& Riniolo, 1999; Van-Ameringen, Mancini, \& Oakman, 1998). The alpha coefficient for the scale is .90 , and the 45 -day test-retest reliability is .88. Generally, moderate to strong correlations have been obtained between the RCBS and other measures of shyness: the SRS-II (Social Reticence Scale; Jones \& Briggs, 1986), r = .77; the Shyness Questionnaire (Bortnik et al., 2002), $\mathrm{r}=.74$; responses to the question, "How shy are you?" (Hopko et al., 2005), $\mathrm{r}=.56$; the Fear of Negative Evaluation Scale (FNE) (Watson \& Friend, 1969), $r=.63$; the Social Phobia Scale (SPS) (Mattick \& Clarke, 1998), r = .56; and the Social Interaction Anxiety Scale (SIAS) (Mattick \& Clarke, 1998), r $=.84$. Convergent validity of the RCBS was also supported via strong correlations with the above-mentioned measures (see Hopko et al., 2005, for a review). Moreover, the correlation with the original 9-item version was .96. In an attempt to discriminate the constructs of shyness and sociability, the items were written to measure affective and behavioral aspects of shyness without referring to the desire to seek out or avoid social interactions ( $\mathrm{r}=-.30)$ (Leary, 1991). The negative but low to moderate correlations between shyness and sociability also indicate that shyness is something other than low sociability.

2. Language Learning Orientation Scale - Intrinsic Motivation, Extrinsic Motivation and Amotivation Subscales (LLOS-IEA)

The LLOS-IEA (Noels et al., 2000) was adapted from the Academic Motivation Scale (AMS) (Vallerand et al., 1989, 1992, 1993.) The AMS was translated from French into English through parallel back-translation procedure, using two independent back translation sequences. The AMS has 28 items measuring seven subscales: amotivation, external regulation, introjected regulation, identified regulation, and three dimensions of intrinsic motivation (i.e., knowledge, accomplishment, and stimulation). The latter dimensions were added to the original view of intrinsic motivation from Self-Determination Theory by Vallerand and his colleagues (Vallerand et al., 1989), indicating intrinsic motivation to know, to accomplish things, and to experience stimulation.

Intrinsic motivation to know can be defined as the feeling an individual experiences when he or she engages in an activity for the pleasure and fulfillment of learning and exploring something new, whereas intrinsic motivation to accomplish refers to a sensation that one would experience when attempting to accomplish or create something. Lastly, intrinsic motivation to experience stimulation refers to an emotion an individual undergoes when seeking out opportunities to gain sensory pleasures, aesthetic experiences, and excitement.

For these seven subscales, the LLOS-IEA has 21 items. The original LLOSIEA used a 7-point rating scale. However, to correspond with the scaling systems of the other measures used in the present study and in order not to confuse the participants, a 5-point scale was adopted, with 1 being strongly disagree and 5 being strongly agree. Each subscale consists of three items, thus, subscale scores can range from 3 to 15. A high score on a subscale denotes high endorsement of that particular academic motivation towards English learning

For the seven subscales that were used in the study, items on the amotivation subscale reveal the lack of motivation regarding English learning in respondents, and an example is, "I cannot see why I study English, and frankly, I don't care." Items on the external regulation subscale signal that a respondent would engage in English learning only because of outward rewards or punishment, and an example is, "I study English because I have the impression that it is expected of me." Items measuring introjected regulation indicate that respondents learn English to either avoid guilt or anxiety or to obtain an ego boost. An example is, "I study English to show myself that I am a good citizen because I can speak a 
second language." Items measuring identified regulation show that a respondent identifies English learning as something he or she values, and an example is, "I study English because I choose to be the kind of person who can speak more than one language." As for the three dimensions of the intrinsic motivation subscale, a sample intrinsic motivation-knowledge item is, "I study English for the pleasure that I experience in knowing more about English literature." A sample intrinsic motivation accomplishment item is, "I study English for the pleasure I experience when surpassing myself in my English studies." Lastly, a sample intrinsic motivation-stimulation item is, "I study English for the 'high' I feel when hearing English spoken."

The Cronbach alpha index of internal consistency of the LLOS-IEA was acceptable for all subscales, ranging from .67 to .88 (Noels et al., 2003). In the current study the cronbach alpha index of internal consistency calculated is 76.9.

3. The Willingness-To-Communicate Scale (WTC)

The WTC scale was developed to measure a respondent's propensity toward approaching or avoiding the initiation of communication (McCroskey \& Richmond, 1987). The scale has 20 items, eight of which are fillers and 12 that are scored as part of the scale. It yields a total score, three subscores based on the types of interlocutors (strangers, acquaintances, and friends), and four subscores based on the nature of communication contexts (public speaking, meeting, and group discussion, and interpersonal). Originally, the scale was scored on a 100-point scale. However, to be consistent with the scaling system of other measures used in this study and in order not to confuse the participants, a 5point scale was adopted, with 1 being $I$ never do this, and 5 being I always do this. The subscores were obtained by adding the scores of selected items on particular subscales and calculating an average, whereas the total score was computed by adding subscores for the contexts of communicating with strangers, acquaintances, and friends and dividing the sum by three.

Higher scores indicate a respondent's readiness to initiate conversations with others under the circumstance in which they find themselves.

Since the scale was developed in the 1980s based on the societal context of the United States, modern day Iranian students may not be able to relate themselves to the situation which was described in certain items. For example, with the item of "willing to communicate with a service station attendant," the receiver of the communication was changed to "salesperson who sells tickets in a booth at a local movie theater," because students could easily associate the statement with their experience and imagine themselves in the situation. Furthermore, additional examples were added to certain items to help students conceptualize the situation that was depicted.

Studies conducted by McCroskey and his colleagues have found estimates of internal reliability of the total score of the scale to range from .86 to .95 . Reliability estimates for the context subscores ranged from .60 to .83 , while estimates for the receiver subscores ranged from .70 to .91 (Estimates obtained from data collected in other countries, such as Australia and Japan have been consistent with those generated from U.S. data (Barraclough, Christophel, \& McCroskey, 1988; Yashima, Zenuk-Nishide, \& Shimizu, 2004). In the current study the cronbach alpha index of internal consistency calculated is 88.9 .

\section{Data Collection Procedures}

Before going into the classrooms, consent from the instructors was obtained. In addition, students were informed of the purpose of the study by their respective instructors. On the day of the questionnaire administration, instructors taught for the first half of the class time, one hour, and left one hour for the researcher to conduct the survey. To ensure consistency in the questionnaire administration, the researcher gave instructions and proctored the survey herself. At the beginning of each questionnaire administration, the instructor of each section introduced the researcher and left the room. The students were informed that participation in the study would be on a voluntary basis and that it would not by any means affect their grade in the course. Students who agreed to participate in the study were given 30 minutes to finish the questionnaire booklets that consisted of the above-mentioned instruments

\section{Data Analysis}

After the required data were collected, they were put into the spreadsheets and analyzed using SPSS, Version 16.0. Descriptive statistics such as mean, standard deviation and range were computed for each questionnaire. After that Pearson Product Moment Correlation was run to find out if there was a relationship between shyness and language learning orientation, learning motivation and willingness to communicate and, shyness and willingness to communicate. To answer the first and the second questions t-test (independent sample) was run.

\section{RESULTS}

The analyses referred to in this chapter included the entire sample of 60 students. They provide a glimpse into Iranian EFL learners' shyness, their self-determined motivation regulations towards their English studies, and their level of willingness to communicate.

\section{A. Descriptive Statistics of the Revised Cheek and Buss Shyness Scale}


With the lowest possible score of 13 and highest possible score of 65, the mean of the total scores on the Revised Cheek and Buss Shyness Scale (RCBS) for the 60 participants was 35.08 ( $\mathrm{SD}=6.31$ ), which indicated that this group, as a whole, was somewhat shy. The lowest score in the group was $18(n=1)$, while the highest was $51(n=1)$. Using the cutoff score of 39 recommended by Cheek, the participants were divided into groups of shy and non-shy individuals. Seventy percent of the students were non-shy and $30 \%$ were shy.

\section{B. Descriptive Statistics of the Language Learning Orientation Scale}

Among the seven subscales of the Language Learning Orientation Scale - Intrinsic Motivation, Extrinsic Motivation and Amotivation Subscales (LLOS-IEA), intrinsic motivation to stimulate was the type of motivation that most participants reported having the most towards their English learning, followed by identified regulation, intrinsic motivation to accomplish, intrinsic motivation to know, external motivation, introjected motivation and amotivation. It is reasonable to see that the participants endorsed amotivation regulation the least.

\section{Descriptive Statistics of the Willingness to Communicate Scale}

When being asked how willing they are to communicate with others, the participants showed a preference for feeling more comfortable talking with friends, while they reported feeling least comfortable talking with strangers. They also reported more willingness to talk in groups and the least willingness to talk in meetings.

\section{Shyness and Motivation}

To determine if shy and non-shy students report having different types of motivation the statistical procedure of t-test (Independent sample) was run. The results show that shy and non-shy students do not show different types of motivation except for the intrinsic motivation to accomplish. The result in that part is significant $(\mathrm{p}<0.01)$.

\section{E. Shyness and Willingness to Communicate}

To determine If shy and non-shy students report having different levels of willingness to communicate the statistical procedure of t-test (Independent sample) was run again. The results show that shy and non-shy students do not show different levels of willingness to communicate.

\section{F. Motivation and Willingness to Communicate}

To determine the relationship between Iranian EFL learners' motivation and their willingness to communicate the statistical procedure of Pearson correlation was run. The correlation was not significant.

\section{G. Shyness, Motivation and Willingness to Communicate}

Finally to determine the relationship among shyness, Iranian EFL learners' motivation and their willingness to communicate the statistical procedure of Pearson correlation was run. Correlation was significant at the 0.01 level (2tailed).

\section{DISCUSSION}

According to the obtained results, Correlations between variables reveal that shyness has a relationship with language learning motivation. But, motivation does not show a relationship with willingness to communicate. Besides, shyness does not show a relationship with willingness to communicate either.

The results of the t-test analysis (independent sample) reveal that shy and non-shy students show different types of motivation, but they do not show different levels of willingness to communicate.

\section{Discussion on the research questions}

1. Do shy and non-shy students report having different types of motivation in EFL learning?

Unlike most of the studies in which the constructs of integrative and instrumental motivation were used to investigate the students' motivation to learn English (Gardner, 1985), in this study self-determination theory (Deci \& Ryan, 1995) was adopted, and the motivation continuum proposed by Deci and Ryan was used as a basis for measuring the learners' motivation. Non-shy students reported having more intrinsic motivation to accomplish than shy students.

2. Do shy and non-shy learners show different levels of willingness to communicate?

As for the relationship between shyness and willingness to communicate, a student who reports himself to be shy is expected to be less likely to initiate interactions with others. Among the four communication contexts (group discussions, meetings, interpersonal, and public speaking), students reported their preference to interact with others in group discussions the most and in meetings the least. This finding can be understood in the light of how a group discussion is carried out in Iranian classrooms, regardless of levels of education. When a group discussion occurs, not all of the participants are expected to participate. Some students may dominate the discussion and take the floor most of the time, whereas the timid ones can sit back and just nod in agreement without the need for saying much. Compared to the interaction occurring in interpersonal relationships in which each interlocutor has an equal share of keeping the conversation going, group discussion poses less demand on its participants, especially for shy ones. Therefore, it is not surprising that this mode of communication was most favored by shy students. However, it is somewhat puzzling to explain non-shy students' preference for talking in groups. 
As for the preference for interacting with three types of interlocutors (strangers, acquaintances, and friends), speaking with friends was favored by most students, whereas talking to strangers was ranked as the least favorite. This finding is without a doubt intuitive because individuals are likely to feel most comfortable in interacting with those whom they are familiar with. However, Table 4.15 revealed that in the sample under study there was not a significant difference between shy and non-shy learners' level of willingness to communicate.

3. Is there a relationship between Iranian EFL learners' language learning motivation and their willingness to communicate?

The two variables did not show any relationship in the sample chosen for this study.

4. Is there a relationship among Iranian EFL learners' shyness, their language learning motivation and their willingness to communicate?

According to the results, there is a significant positive relationship between shyness and students' motivation ( $\mathrm{p}<$ 0.01)which means increase in shyness is associated with high motivation but motivation and willingness to communicate do not show any relationship $(\mathrm{p}<0.01)$. Besides, shyness and willingness to communicate do not have a significant correlation either. $(\mathrm{p}<0.01)$.

\section{CONCLUSION}

As was already mentioned, the experience of learning a foreign language for most learners is both cognitively and emotionally demanding. Most learners learn a foreign language in classrooms, where there is constant performance evaluation by the instructor and peers. Such a situation can be frightening, especially for those learners who are shy, because they fear negative evaluation. By identifying these learners, teachers may become aware of the type of motivation they have toward EFL learning, estimate their level of willingness to communicate, and be able to identify strategies that match these students' study needs.

English instructors that have similar settings as the one sampled in this study may feel relieved to know that the majority of their students are relatively motivated to learn English in their required English courses. However, because the results reported in this study cannot be generalized to all students who are learning English in Iran, it is up to instructors to find out what encourages their students to practice English, given the variables that were investigated in this study. Using the information of students' personality trait (e.g. shyness), and willingness to communicate, an instructor can judge the participation in class activities that he or she may want to use and make modification to the curriculum accordingly. For example, if there were more shy students who were reluctant to speak up in class, pair work or individual activities can take up a larger portion of the curriculum, to help create a low-risk learning environment. On the other hand, if the majority of the students in class were non-shy and were willing to take risks in their English learning behavior, an instructor can implement activities that require them to experiment, whether it is with the new strategies they acquired or the new vocabulary they have just learned, or provide opportunities for them to explore the possibilities of learning English anytime, anywhere.

Nonetheless, despite students' personality, willingness to communicate, level of anxiety experienced in their English class, instructors need to bear in mind that in order to assist their students in becoming effective and adaptive learners, they need to stretch their students' English-learning muscles by presenting an array of possibilities, may it be a new way of memorizing vocabulary, a new medium with which students can learn English, or an alternative assessment of students' progress. By guiding students through multiple options, the instructors can help them make informed decisions regarding their English studies. Surely, the same principle can be very well extended to other disciplines of students' studies.

\section{REFERENCES}

[1] Anthony, E. (1963). Approach, method, and technique. English Language Teaching, 17(1), 63-67.

[2] Asendorph, J. B. (2000). Shyness and adaptation to the social world of university. In W. R.Crozier (Ed.), Shyness: Development, consolidation and change (pp. 103-120). London: Routledge.

[3] Burgoon, J. K. (1976). The unwillingness-to-communicate scale: Development validation. Communication Monographs, 43, 60-69.

[4] Buss, A. H. (Ed.). (1980). Self-consciousness and social anxiety. San Francisco: W. H. Freeman and Company.

[5] Caspi, A., Elder, G. H., \& Bem, D. J. (1988). Moving away from the world: life-course plans of shy children. Developmental Psychology, 24, 824-831.

[6] Chan, B. \& McCroskey, J. C. (1987). The WTC scale as a predictor of classroom participation. Communication Research Reports, 4, 47-50.

[7] Cheek, J. M. (1983). The revised Cheek and Buss shyness scale (RCBS). Unpublished manuscript, Wellesley College, Wellesley, MA.

[8] Cheek, J. M., \& Buss, A. H. (1981). Shyness and sociability. Journal of Personality and Social Pscyhology, 41(2), 330-339.

[9] Chuh, R. H. (2008). Shyness and EFL Learning in Taiwan: A Study of Shy and Non-shy College Students' Use of Strategies, Foreign Language Anxiety, Motivation, and Willingness to Communicate. Unpublished doctoral dissertation, The University of Texas, Austin.

[10] Clement, R. (1980). Ethnicity, contact and communicative competence in a second language. In H. Giles, W. P. Robinson \& P. M. Smith (Eds.), Language: Social psychological perspectives (pp.147-154), Oxford: Pergamon. 
[11] Clement, R., Baker, S. C., \& MacIntyre, P. D. (2003). Willingness to communicate in a second language: the effect of context, norms, and vitality. Journal of Language and Social Psychology, 22, 190-209.

[12] Clement, R., Dornyei, Z., \& Noels, K. (1994). Motivation, self-confidence and group cohesion in the foreign language classroom. Language Learning, 44, 417-448.

[13] Clement, R., \& Gardner, R. C. (2001). Second language mastery. In H. Giles \& W. P. Robinson (Eds.), The new handbook of language and social psychology (2nd ed.). London: Wiley.

[14] Clement, R., \& Kruidenier, B. G. (1985). Aptitude, attitude and motivation in second language proficiency: A test of Clement's model. Journal of Language and Social Psychology, 4, 21-37.

[15] Clement, R., Smythe, P. C., \& Gardner, R. C. (1978). Persistence in second language study: Motivational considerations. Canadian Modern Language Review, 34, 688-694.

[16] Crookes, G., \& Schmidt, R. (1991). Motivation: Reopening the research agenda. Language Learning, 41, 469-512.

[17] Deci, E. L., \& Ryan, R. M. (Eds.) (2002). Handbook of self-determination. Rochester: University of Rochester Press.

[18] Dewaele, J. -M., \& Furnham, A. (1999). Extraversion: the unloved variable in applied linguistic research. Language Learning, 49(3), 509-544..

[19] Dewaele, J. -M., \& Furnham, A. (2000). Personality and speech production: A pilot study of second language learners. Personality and Individual Differences, 28, 355-365.

[20] Dornyei, Z. (1994). Understanding second language motivation: On with the challenge! The Modern Language Journal, 78 , 515-523.

[21] Dornyei, Z. (1999). Motivation. In B. Spolsky (Ed.), Concise encyclopedia of educational linguistics (pp.525-532). Oxford: Pergamon.

[22] Duncan, J., \& Paulhus, D. L. (1998, August). Varieties of shyness in Asian- and European-Canadians. Paper presented at the 106th Annual Convention of the American Psychological Association, San Francisco, CA.

[23] Dunkel, H. B. (1947). The effects of personality on language achievement. Educational Psychology, 38, 177-182.

[24] Entwistle, N. J. (1972). Personality and academic attainment. British Journal of Educational Psychology, 42(2), $137-151$.

[25] Friedman, P. G. (1980). Shyness and reticence in students. Washington, DC: National Educational Association.

[26] Gardner, R. C. (1985). Social psychology and second language learning: The role of attitudes and motivation. London: Edward Arnold.

[27] Gardner, R. C., \& Lambert, W. E. (1959). Motivational variables in second language acquisition. Canadian Journal of Psychology, 13, 266-272.

[28] Gardner, R. C., \& MacIntyre, P. D. (1993). On the measurement of affective variables in second language learning. Language Learning, 43, 157-194.

[29] Gardner, R. C., \& Smythe, P. C. (1975). Second language acquisition: A social psychological approach (Research Bulletin No. 332). Ontario: University of Western Ontario.

[30] Gardner, R. C., \& Smythe, P. C. (1981). On the development of the Attitude/Motivation Test Battery. Canadian Modern Language Review, 37, 510-525.

[31] Gardner, R. C., Smythe, P. C., \& Brunet, G. R. (1977). Intensive second language study: Effects on attitudes, motivation, and French achievement. Language Learning, 27, 243-261.195

[32] Gardner, R. C., Tremblay, P. F., \& Masgoret, A. -M. (1997). Towards a full model of second language learning: An empirical investigation. The Modern Language Journal, 81, 344-362.

[33] Hajimohammadi,R.(2011). Impact of self correction on extrovert and introvert students in EFL writing progress. . English Language Teaching, 4,3-5.

[34] Heiser, N. A., Turner, S. M., \& Beidel, D. C. (2003). Shyness: Relationship to social phobia and other psychiatric disorders. Behavior Research and Therapy, 41, 209-221.

[35] Heiser, N. A. (2005). Differentiating social phobia from shyness. Unpublished doctoral dissertation, University of Maryland, College Park.

[36] Hopko, D. R., Stowell, J., Jones, W. H., Armento, M. E. A., \& Cheek, J. M. (2005). Psychometric properties of the revised Cheek and Buss shyness scale. Journal of Personality Assessment, 84(2), 185-192.

[37] Hosseini, M ., \& Kafipour, R. (2011). The relationship among extraversion tendency, vocabulary learning strategies, and reading comprehension of EFL undergraduates in Kerman province. Studies in Literature and Language, 3, 104-110.

[38] Jones, W. H., Briggs, S. R., \& Smith, T. G. (1986). Shyness: Conceptualization and measurement. Journal of Personality and Social Psychology, 51, 629-639.

[39] Jones, W. H., \& Russell, D. (1982, December). The social reticence scale: An objective instrument to measure shyness. Journal of personality assessment, 46(6), 629-631.

[40] Kang, S. -J. (2005). Dynamic emergence of situational willingness to communicate in a second language. System, 33, $277-292$.

[41] Leary, M. R. (1991). Social anxiety, shyness, and related constructs. In J. P. Robinson, P. R. Shaver, \& L. S. Wrightsman (Eds.), Measures of personality and social psychological attitudes (pp. 182-184). San Diego, CA: Academic.

[42] Leary, M. R., \& Schlenker, B. R. (1981). The social psychology of shyness: A selfpresentational model. In J. T. Tedeschi (Ed.), Impression management theory and social psychological research. New York: Academic Press.

[43] Long, M. H. (1996). The role of the linguistic environment in second language acquisition. In W. C. Ritchie \& T. K. Bhatia (Eds.), Handbook of second language acquisition (pp. 413-468). New York: Academic Press.

[44] MacIntyre, P. D. (1994). Variables underlying willingness to communicate: A causal analysis. Communication Research Reports, 12, 241-247.

[45] MacIntyre, P. D., Baker, S. C., Clement, R., \& Donovan, L. A. (2001). Willingness to communicate, social support, and language-learning orientations of immersion students. Studies in Second Language Acquisition, 23, 369-388.

[46] MacIntyre, P. D., Baker, S. C., Clement, R., \& Donovan, L. A. (2003a). Talking in order to learn: Willingness to communicate and intensive program. Canadian Modern Language Review, 59, 589-607. 
[47] MacIntyre, P. D., \& Gardner, R. C. (1994). The subtle effects of language anxiety on cognitive processing in the second language. Language Learning, 44, 283-305.

[48] MacIntyre, P. D., Noels, K. A., \& Clement, R. (1997). Biases in self-ratings of second language proficiency: The role of language anxiety. Language Learning, 47, 265-287.

[49] Mackey, A. \& Gass, S. (2006). Pushing the methodological boundaries in interaction research: An introduction to the special issue, Studies in Second Language Acquisition, 28(2), 169-178.

[50] McCroskey, J. C. (1992). Reliability and validity of the willingness to communicate scale. Communication Quarterly, 40, 1625.

[51] McCroskey, J. C., \& Baer, J. E. (1985). Willingness to communicate: The construct and its measurement. Paper presented the annual convention of the Speech Communication Association, Denver, CO.

[52] McCroskey, J. C., \& McCroskey, L. L. (1986a). Correlates of willingness to communicate. Paper presented at the annual convention of the Western Speech Communication Association, Tucson, AZ

[53] McCroskey, J. C., \& Richmond, V. P. (1987). Willingness to communicate. In J. C. McCroskey \& J. A. Daly (Eds.), Personality and interpersonal communication (pp. 129-156). Beverly Hills, CA: Sage.

[54] Miller, R. S. (1995). On the nature of embarrassibility: Shyness, social evaluation and social skill. Journal of Personality, 63, 315-339.

[55] Morris, L. W. (1979). Predicting anxiety experiences and academic performance in two groups of students. Journal of Educational Psychology, 70(4), 589-594

[56] Mortensen, D. C., Arntson, P. H., \& Lustig, M. (1977). The measurement of verbal predispositions: Scale development and application. Human Communication Research, 3, 146-158.

[57] Nemati,M.,\& Shahini,A. (2011). The relationship between extroversion and introversion and the oral proficiency of Iranian EFL learners. Iranian EFL journal, 7, 55-65.

[58] Noels, K. A. (2001a). Learning Spanish as a second language: Learners' orientations and perceptions of their teachers' communication style. Language Learning, 51, 107-144.

[59] Noels, K. A. (2001b). New orientations in language learning motivation: Toward a contextual model of intrinsic, extrinsic, and integrative orientations and motivation. In Z. Dornyei \& R. Schmidt (Eds.), Motivation and second language acquisition (pp.43-68). Honolulu: University of Hawaii Press.

[60] Noels, K. A., \& Clement, R. (1996). Communicating across cultures: Social determinants and acculturative consequences. Canadian Journal of Behavioral Science, 28, 214-228.

[61] Noels, K. A., Clement, R., \& Pelletier, L. G. (1999). Perceptions of teachers' communicative style and students' intrinsic and extrinsic motivation. The Modern Language Journal, 83, 23-34.

[62] Noels, K. A., Clement, R., \& Pelletier, L. G. (2001). Intrinsic, extrinsic, and integrative orientations of French Canadian learners of English. Canadian Modern Language Review, 57, 424-444.

[63] Noels, K. A., Pon, G., \& Clement, R. (1996). Language, identity and adjustment: the role of linguistic self-confidence in the adjustment process. Journal of Language and Social Psychology, 15, 246-264.

[64] Oller, J. W. (1981). Research on the measurement of affective variables: Some remaining questions. In Andersen, R. (Ed.), New dimensions in second language acquisition research. Rowley, MA: Newbury House Publishers.

[65] Paulhus, D. L., Duncan, J. D., \& Yik, M. S. M. (2002). Patterns of shyness in students of European and East-Asian heritage. Journal of Research in Personality, 36, 442- 462.

[66] Paulhus, D. L., \& Trapnell, P. D. (1998). Typological measures of shyness: Additive, interactive, and categorical. Journal of Research in Personality, 32, 183201

[67] Pazouki, M., (2009). Extraversion-Introversion, Shyness, and EFL Proficiency. Psychological Research, 12, 78-91

[68] Phillips, E. M. (1980). The effects of anxiety on performance and achievement in an oral test of French. Unpublished Doctoral Dissertation: the University of Texas, Austin.

[69] Pilkonis, P. A. (1976). Shyness: Public behavior and private experience. Unpublished doctoral dissertation, Stanford University, Stanford, CA.

[70] Pilkonis, P. A. (1977a). Shyness, public and private and its relationship to other measures of social behavior. Journal of Personality, 45(4), 585-595.

[71] Pilkonis, P. A. (1977b). The behavioral consequences of shyness. Journal of Personality, 45(4), 596-611.

[72] Rastegar, M. (2002). The effect of self-esteem, extraversion and risk-taking on EFL proficiency of TEFL students. Journal of the Faculty of Letters and Humanities, 10, 9-35.

[73] Schmidt, L. A., \& Tasker, S. L. (2000). Childhood shyness: Determinants, development, and ‘depathology'. In W. R. Crozier (Ed.), Shyness: Development, consolidation and change (pp. 30-46). New York: Routledge.

[74] Schmidt, R., Boraie, E. \& Kassagby, O. (1996). Foreign language motivation: Internal structure and external connections. In R. L. Oxford (Ed.), Language learning motivation: Pathways to the new century (pp.9-70). Manoa: University of Hawaii Press.

[75] Swain, M. (2005). The output hypothesis: Theory and research. In E. Hinkel (Ed.), Handbook of research in second language teaching and learning (pp. 471-483). Mahwah, NJ: Lawrence Erlbaum Associates.

[76] Theall-Honey, L. A., \& Schmidt, L. A. (2006). Do temperamentally shy children process emotion differently than nonshy children? Behavioral, psychophysiological, and gender differences in reticent preschoolers. Developmental Psychobiology, 48(3), 187-196

[77] Vaezi, Z. (2008). Language learning motivation among Iranian undergraduate students. World Applied Sciences Journal, 5(1), 54-61.

[78] Van-Ameringen, M., Mancini, C., \& Oakman, J. M. (1998). The relationship of behavioral inhibition and shyness to anxiety disorder. Journal of Nervous and Mental Disease, 186, 425-431.

[79] Vallerand, R. J. (1997). Toward a hierarchical model of intrinsic and extrinsic motivation. In M. P. Zanna (Ed.), Advances in experimental social psychology (Vol. 29, pp. 271-360). San Diego, CA: Academic Press. 
[80] Vallerand, R. J., Blais, M. R., Briere, N. M., \& Pelletier, L. G. (1989). Construction and validation of the Motivation toward Education Scale. Canadian Journal of Behaviour Science, 21(3), 323-349.

[81] Vallerand, R. J., Pelletier, L. G., \& Blais, M. R. (1992). The Academic Motivation Scale: A measure of intrinsic, extrinsic, and amotivation in education. Educational and Psychological Measurement, 52(4), 1003-1017.

[82] Vallerand, R. J., Pelletier, L. G., Blais, M. R., Briere, N. M., Senecal, C., \& Vallieres, E. F. (1993). On the assessment of intrinsic, extrinsic and amotivation in education: Evidence on the concurrent and construct validity of the Academic Motivation Scale. Educational and Psychological Measurement, 53, 159-172.

[83] Watson, D. \& Friend, R. (1969). Measurement of social-evaluative anxiety. Journal of Consulting and Clinical Psychology, 33, 448-457.

[84] Yashima, T. (2002). Willingness to communicate in a second language: the Japanese EFL context. Modern Language Journal, 86, 54-66.

[85] Yashima, T., Zenuk-Nishide, L., \& Shimizu, K. (2004). The influence of attitudes and affect on willingness to communicate and second language communication. Language Learning, 54(1), 119-152.

[86] Zarinabadi. N. (2011). Willingness to communicate and language learning orientations in Iranian EFL context. International education studies, $54,170-178$

[87] Zimbardo, P. G. (Ed.). (1977). Shyess: What it is, what to do about it. Reading, MA: Addison-Wesley Publishing Company.

[88] Zimbardo, P. G., Pilkonis, P. A., \& Norwood, R. M. (1974). The silent prison of shyness. Office of Naval Research Tech: Stanford University.

Tannaz Mohammadian was born in Shiraz, Iran on 27 December, 1984. She got her bachelor's degree In English literature at Shiraz State University, Shiraz, Iran in 2007. Later she received her master's degree in teaching English as a foreign language at Shiraz Azad University, Shiraz, Iran in 2013.

She worked as an ENGLISH INSTRUCTOR at different reputable English institutes in Shiraz, Iran since 2004 and is currently working at Iran Language Institute as an ENGLISH INSTRUCTOR, and at Eram University of Shiraz as a professor. Her current research interest is factors affecting Iranian EFL learners listening comprehension. 